\title{
PERAN TIME MANAGEMENT TERHADAP PERILAKU DAN PERSEPSI MAHASISWA DALAM ORGANISASI
}

\author{
Agnes Cornelia J Abi, Kimiaus Saadah \\ Universitas Trunojoyo Madura
}

\begin{abstract}
This scientific article aims to provide an overview of how much time management influences students 'behavior and perceptions when they are members of the Student Activity Unit (UKM) at the Trunojoyo Madura University (UTM) and also analyzes the factors that influence students' perceptions of being a member of UKM. Time management is important to be studied by members of SMEs in order to improve the quality of human resources (HR) and organizational quality, in addition to this student perception is also useful to anticipate the cessation of SME members, the data collection method used in writing this article is collecting questionnaire data, for students who are still active as members of SMEs and students who are not active or stop being members of SMEs, the results obtained in the discussion of this article are time management, perception and interest greatly influence the activeness of students to become members of the organization
\end{abstract}

Keywords: Time management, Perception, Organization

\section{PENDAHULUAN}

Mahasiswa merupakan salah satu komponen penting untuk menunjang kemajuan negara. Oleh karena itu mahasiswa diharapkan bisa mengaplikasikan segala macam ilmunya bagi kepentingan bangsa dan negara. Namun kesulitan dalam memperoleh pekerjaan saat ini membuat seorang mahasiswa harus menempuh studinya lebih berat lagi, karena hanya mahasiswa yang memiliki nilai/prestasi yang baik saja yang bisa membuat mereka lebih mudah mendapatkan pekerjaan yang layak kedepannya nanti. Paradigma seperti itulah yang saat ini menimpa mahasiswamahasiswi di Indonesia yang menyebabkan mahasiswa kurang berminat mengikuti suatu organisasi di kampus. Padahal, tidak hanya hard skill (ilmu) saja yang harus dikuasai dalam dunia kerja, tetapi juga soft skill (sosial) yang ternyata juga harus lebih dikembangkan dalam sosok seorang mahasiswa.

Organisasi mahasiswa (Ormawa) di tingkat universitas terdiri atas Badan Eksekutif Mahasiswa (BEM), dan Dewan Perwakilan Mahasiswa (DPM). Sedangkan Ormawa di tingkat Fakultas terdiri dari Badan Ekesekutif Mahasiswa Fakultas (BEMF) dan Dewan Perwakilan Mahasiswa Fakultas, dan di tingkat jurusan/program studi terdapat Himpunan Mahasiswa Program Studi (HMP). 
Sementara itu, untuk mewadahi minat, bakat, dan pembinaan prestasi mahasiswa, terdapat Unit Kegiatan Mahasiswa (UKM) di tingkat universitas dan fakultas. Dan agar tercapai suatu keteraturan dan penyaluran yang tepat maka dibentuklah adanya pembinaan bidang Ormawa. Unit kegiatan mahasiswa merupakan tempat mahasiswa untuk mengembangkan minat, keahlian dari masing-masing mahasiswa dan kemampuan untuk bersosialisasi dengan dunia luar. Dengan mengikuti UKM banyak sekali sisi positif yang bisa diambil, salah satunya dengan mengikuti kegiatan UKM kita juga akan mengetahui atau mengenal mahasiswa dari jurusann lain.

\section{TINJAUAN PUSTAKA}

\section{Pengertian Time Management}

Time management adalah tentang perencanaan hari/waktu supaya bisa melakukan penggunaan paling baik atas waktu yang dimiliki. Konsep atau istilah mengenai time management berawal dari revolusi industri, yaitu ketika mulai ada perhatian tentang pengelolaan waktu secara efektif dan efisien untuk bisa mengontrol waktu yang dimiliki seseorang. Sejak Drucker (2006:13) mempopulerkannya, konsep time management ini telah secara luas diterima sebagai hal yang menyumbang pada efektivitas karyawan (Adebisi, 2013). Waktu adalah sumber daya berharga, tidak dapat diganti dan tidak dapat diubah. Maka dari itu, sangat perlu untuk menggunakan waku dengan bijaksana. Time management mencakup tindakan menata, menjadwal, mengorganisasi, dan mengalokasikan setiap waktu seseorang yang digunakan untuk menyelesaikan tugas-tugas hariannya. König (2007) mendefinisikan management sebagai proses organisasi, yang meliputi perencanaan strategis, penataan, penetapan tujuan, pengelolaan sumber daya, pengembangan manusia dan aset keuangan yang dibutuhkan untuk meraih tujuan dan mengukur hasilnya. Sedangkan time management merupakan seni menata urusan bisnis dan pribadi seefektif dan seefisien mungkin, membuat semuanya terlaksana dengan baik, secepat mungkin, dan dengan penggunaan sumber daya (waktu, energi, uang dan manusia) sesedikit mungkin. Tujuan utama di balik semua usaha itu adalah untuk menghemat waktu lama yang diperlukan untuk pelaksanaan tugas atau pekerjaan. Dengan kata lain, itu adalah suatu seni menata, mengorganisasi, menjadwal, dan menganggarkan waktu yang tersedia untuk tujuan menghasilkan kerja lebih efektif dan produktif. Menurut Kusashi (dalam Adebisi, 2013), menunda pengambilan suatu keputusan atau bersikap reaktif terhadap 
suatu problem dapat mengakibatkan biaya mahal yang harus ditanggung oleh bisnis. Maka diperlukan sekali untuk memastikan bahwa pimpinan tidak melakukan kesalahan, dengan menunda pemanfaatan waktu yang sangat berharga bagi perusahaan. Time management yang baik akan sangat membantu perusahaan lebih produktif, lebih kreatif, menghemat banyak uang, dan menghindari bekerja pada saat-saat yang sudah kritis, dan secara meyakinkan dapat meningkatkan kesempatan meraih keberhasilan dalam bisnis

\section{Pentingnya Penerapan Time Management}

Masalah time management merupakan hal umum bagi banyak orang. Banyak orang mengakui dan merasakan tentang perlunya, tetapi dalam kenyataannya mereka tidak memerhatikan dan menerapkannya. Tentang mengapa time management menjadi masalah bagi manusia, baru sekarang ini mendapat perhatian para peneliti. Khususnya, para ekonom dan dan psikolog telah mengembangkan argumen teoretis tentang mengapa time management berat bagi banyak orang. Salah satunya karena kurangnya keterampilan dan keberanian dalam mengembangkan dan menerapkan time management dalam kehidupan (Fischer, 2008:15). Fischer (2008) juga mencatat temuan dari teori behavioral decision bahwa orang sering mengabaikan hasil besar di masa depan yang bisa didapatkan ketika menerapkan time management yang bagus. Artinya, pengembangan dan penerapan time management itu hasilnya tidak selalu kelihatan pada tahap awal penerapannya, namun setelahnya, dengan penerapan yang konsisten, hasilnya bisa sangat mengagumkan. Jika hasil di masa depan tidak dipikirkan dalam time management yang dibuat kini, orang bisa jadi akan menggunakan waktu mereka untuk hasil-hasil yang sesegera mungkin bisa didapatkan, yang biasanya lebih kecil dari hasil-hasil lainnya, yang didapatkan kemudian dalam waktu yang jauh ke depan. Dengan kata lain, orang lebih suka hal-hal yang mendesak tetapi tidak penting ketimbang hal-hal penting tetapi tidak mendesak.

Time management yang bagus sangat penting untuk mengatasi tekanan-tekanan dari dunia modern ini tanpa mengalami terlalu banyak stres. Time management yang bagus tidak berarti melakukan banyak pekerjaan, melainkan berfokus pada tugas setepatnya dan membuat perbedaan. Apakah di dalam pekerjaan atau di kehidupan secara keseluruhan, seorang harus belajar bagaimana mengelola waktu secara baik, yang akan membantu merasa lebih relaks, fokus, dan terkontrol. Menurut Donaldson (dalam Adebisi, 2013) "The aim of good time management is to achieve the lifestyle balance you want." Waktu yang 
bagus dalam pekerjaan berarti melakukan pekerjaan berkualitas tinggi, bukan terutama tinggi dalam hal kuantitas. Claessens, et al (2007) menemukan bahwa menggunakan teknik time management akan berhubungan langsung dengan kinerja dan kepuasan, serta dapat mengurangi kegalauan dan kecemasan.

\section{Hal Penting yang Diperhatikan dalam Perancangan Time Management}

Seseorang butuh menginvestasikan sumber daya berharga dari waktu untuk hal yang sangat penting. Scott (dalam Adebisi, 2013) memperjelas bahwa satu tantangan mendasar time management yang efektif adalah memahami perbedaan antara "urgent" dan "important", "mendesak" dan "penting". "Mendesak" sendiri tidak membuat tugas itu penting. Hal "penting" itu terkait dengan prinsip pribadi. Prioritas bisnis yang menentukan hal penting dari kerja. Dengan kejelasan misi dan tujuan pribadi, waktu dijadwalkan dengan tujuan definitif dalam hati. Seorang juga perlu merumuskan apa yang dimaksud dengan time management baginya dan bagaimana itu berkaitan dengan pengelolaan hidupnya. Dalam melakukan hal ini, ada 3 hal penting dari kehidupan yang perlu diperhatikan dalam kaitannya dengan pengelolaan waktu dengan baik, yakni: pekerjaan, kehidupan keluarga (termasuk teman-teman) dan diri sendiri (Atkinson, 2009). Seorang perlu memikirkan dengan baik hal penting yang ingin dicapai dengan nyata: tentang tujuan yang ingin dicapai di tempat kerja, tentang tujuan yang ingin dicapai dengan keluarga, dan tentang tujuan yang berkaitan murni dengan diri sendiri. Misalnya dalam suatu proyek, penerapan time management sangat diperlukan untuk mendukung terjadinya efisiensi bagi pengontrolan kemajuan yang dicapai, untuk menjadwal, dan menjalankan apa yang telah disepakati oleh beberapa pihak yang terlibat.

Time management merupakan salah satu area utama perhatian pimpinan proyek beserta timnya. Dengan adanya time management berarti akan tersedia aturan dalam menjalankan dan memantau kemajuan suatu proyek dan pengambilan keputusankeputusan penting terkait dengannya. Para profesional dari suatu proyek sekarang telah menyadari akan pentingnya hal ini. Dalam suatu proyek, pimpinan proyek dan timnya berjuang keras untuk memenuhi dengan baik jadwal yang sudah dibuat untuk menyelesaikan tugas dengan kualitas yang baik. Sinkronisasi antara berbagai hal dan kepentingan dari beberapa pihak yang terlibat dalam suatu proyek merupakan hal sangat penting untuk diperhatikan. Yang dikatakan terlibat di sini tentu saja bukan hanya 
manusia, tetapi juga berbagai sumber daya lainnya, seperti bahan/materi yang diperlukan, dana, tempat, transportasi, perangkat komputer, perizinan, dan sarana lainnya serta waktu itu sendiri. Dalam tahap operasional, menjadwal pekerjaan, membuat kategorisasi jenis pekerjaan yang harus diselesaikan dalam waktu tertentu, menetapkan kualitas hasil yang diinginkan, dan lain-lain, merupakan sebagian dari hal-hal menarik sekaligus menantang dalam suatu proyek.

Konsep dasar time management adalah penggunaan waktu secara efisien dalam merealisasikan pengerjaan suatu tugas. Para ahli percaya bahwa beberapa hal berikut penting dipertimbangkan dalam perancangan time management yang bagus. Pertama, memprioritaskan tugas-tugas penting, dan didasarkan atas sumber daya yang tersedia. Kedua, mengembangkan perencanaan dan menggunaan waktu yang tersedia dengan cara seefisien mungkin. Ketiga, terus memantau penyimpangan-penyimpangan dan gangguan yang terjadi yang mengganggu jalannya pekerjaan sesuai jadwal. Keempat,mengembangkan efisiensi dan mengurangi tekanan atas jadwal yang telah dibuat termasuk tekanan kepada para individu yang terlibat dalam proyek Pimpinan suatu proyek idealnya harus memprioritaskan tugastugas pengerjaan proyek berdasarkan sumber daya dan tenaga manusia yang tersedia baginya. Mengembangkan perencanaan merupakan kunci sukses manajemen atas sumber daya yang tersedia. Sumber daya dan time management dapat secara efisien dikelola melalui jadwal yang diprogramkan dengan baik. Jadwal yang konstruktif akan memperlihatkan dengan jelas kapan suatu proyek dimulai dan kapan harus selesai. Dalam kurun waktu tersebut antara mulai mengerjakan sampai pada penyelesaiannya- perlu disadari akan terjadi banyak tekanan yang akan mengganggu jadwal dan juga orang-orang yang terlibat di dalamnya. Memahami dengan baik kemampuan tim sebagai keseluruhan akan dapat membantu dalam membuat target yang dapat dicapai secara realistis (Kasturi \& Gransberg,2002).

\section{Persepsi}

Persepsi adalah sebuah proses individu mengorganisasikan dan menginterpretasikan kesan sensoris untuk memberikan pengertian pada lingkungannya. Apa yang kita nilai bias jadi berbeda secara subnansial dengan realitas objektif. Persepsi penting bagi perilaku organisasi karena karena perilaku organisasi karena perilaku orangorang didasarkan pada persepsi mereka tentang apa realita yang ada, bukan mengenai 
realita itu sendiri. Dunia sebagaimana yang dinilai adalah dunia yang penting secara perilaku (Robbins, 2006:103)

\section{Faktor-faktor yang mempengaruhi persepsi}

Persepsi seseorang terhadap suatu objek dapat berbeda dengan orang lain. Perbedaan tersebut dipengaruhi oleh berbagai faktor. Cara kita mempersepsikan situasi sekarang tidak bisa terlepas dari adanya pengalaman sensoris terdahulu. Kalau pengalaman terdahulu itu sering muncul, maka reaksi kita selalu menjadi kebiasaan secara ilmiah benar mengingat respon-respon perceptual yang ditunjukkannya.._Mungkin sembilan puluh persen dari pengalaman-pengalaman sensoris kita sehari-hari dipersepsikan dengan kebiasaan yang didasarkan pada pengalaman terdahulu yang diulang-ulang._Oleh karena itu apa yang kita persepsikan pada suatu waktu tertentu akan tergantung bukan saja pada stimulusnya sendiri, tetapi juga pada latar belakang beradanya stimulus itu. Seperti pengalaman-pengalaman sensoris kita yang terdahulu, perasaan kita pada waktu itu, prasangka-prasangka, keinginan-keinginan, sikap dan tujuan. Kalau di satu pihak proses kognitif saling berkaitan satu sama lain. Kita akan mulai dengan persepsi dianggap sebagai pertemuan antara kognisi dan kenyataan-kenyataan dan juga dianggap sebagai sumber utama dari aktivitas kognitif. Berikut ini dikemukakan beberapa faktor yang mempengaruhi persepsi seseorang menurut para ahli mengemukakan bahwa ada tiga faktor penting yang mempengaruhi persepsi yaitu pegetahuan (knowledge), harapan (expectations) dan penilaian (evaluation).

Terdapat tiga faktor utama yang mempengaruhi persepsi secara umum pada seseorang. Faktor tersebut adalah karakteristik individu, kebutuhan dan faktor situasi. Persepsi ditentukan faktor struktural dan faktor fungsional. Faktor struktural berasal semata-mata dari stimulus fisik dan efek-efek saraf yang ditimbulkan pada sistem saraf individu, sedangkan faktor fungsional berasal dari kebutuhan, pengalaman masa lalu dan lain-lain yang termasuk faktor personal. Persepsi dipengaruhi oleh berbagai faktor diantaranya faktor pengalaman, latar belakang pendidikan, budaya dan agama yang dianut. Pengalaman masa lalu juga sangat mempengaruhi seseorang dalam mempersepsikan suatu obyek.

Ada pula tiga macam faktor yang mempengaruhi persepsi seseorang yaitu:

1. Keadaan stimulus yang dipersepsi, 
2. Situasi atau keadaan sosial yang melatar belakangi stimulus, jika situasi sosial yang melatar belakangi stimulus berebeda hal tersebut akan dapat membawa perbedaan hasil persepsi. Keadaan stimulus dipengaruhi oleh sifat-sifat dan karakteristik yang ditampilkan oleh stimulus yaitu ukuran, intensitas, kontras, pengulangan, gerakan, status, dan kehadiran. Stimulus yang memiliki karakteristik yang sifatnya menonjol akan lebih menarik perhatian, sedangkan perhatian merupakan salah satu faktor yang sangat mempengaruhi persepsi,

3. keadaan orang yang mempersepsi. Keadaan orang yang mempersepsi dipengaruhi oleh harapan dan penilaian terhadap stimulus. Seseorang apabila memiliki harapan dan penilaian yang baik terhadap situasi tertentu, maka akan muncul tindakan selaras dengan situasi yang terjadi, demikian sebaliknya. Pandangan manusia akan mempersepsi sesuatu sesuai dengan pengalaman dan harapan yang ada pada dirinya, sehingga persepsi seseorang terhadap sesuatu dapat bersifat dinamis dan berubah.

Persepsi dengan cara pengungkapan yang agak berbeda juga dikemukakan oleh para ahli dimana ada tiga faktor yang perlu mendapat perhatian dalam persepsi, yaitu:

1. Proses sensoris merupakan proses yang digunakan setiap saat meliputi panca indera dan otot,

2. Faktor interpretasi, yaitu meliputi cara seseorang sebagai unit dinamis dan aktif dalam mengorganisir persepsi, pengalaman masa lalu dan arti stimulus yang terlibat di dalamnya.

3. Faktor penelitian, yaitu merupakan sub aspek dari interpretasi yang memberikan kebijaksanaan pada persepsi dalam arti yang lebih luas. Tanggapan individu terbentuk melalui serangkaian penghayatan serta proses belajar yang berhasil dilalui individu dan keseluruhan proses tersebut merupakan dasar bagi timbulnya tingkah laku individu. Sedangkan menurut Krech dan Crutch Field sebagaimana dikutip oleh Jalaluddin Rakhmad empat faktor yang mempengaruhi persepsi yaitu:

Kebutuhan : Merupakan salah satu dorongan kejiwaan yang mendorong manusia untuk melakukan suatu tindakan, misalnya rangsangan, keinginan, tuntutan dan cita-cita Kesiapan mental : Kesanggupan penyesuaian atau penyesuaian sosial atau keduanya sekaligus untuk menciptakan hubungan-hubungan sosial yang berhasil 
Suasana emosional : Kondisi perasaan yang berkesinambungan, dicirikan dengan selalu timbulnya perasaan-perasaan yang senang atau tidak senang latar belakang atau tata nilai yang dianut oleh seseorang.

Latar belakang budaya merupakan disiplin tersendiri dalam psikologi antar budaya.

Karena persepsi lebih bersifat psikologis daripada merupakan proses penginderaan saja maka ada beberapa faktor yang mempengaruhi:

1. Perhatian yang selektif

Dalam kehidupan manusia setiap saat akan menerima banyak sekali rangsangan dari lingkungannya. Meskipun demikian ia tidak harus menanggapi semua rangsangan yang diterimanya untuk itu individunya memusatkan perhatiannya pada rangsangan-rangsangan tertentu.

2. Ciri-ciri rangsangan

Rangsangan yang bergerak diantara rangsangan yang diam akan lebih menarik perhatian. Demikian juga rangsangan yang paling besar diantara yang paling kecil; yang kontras dengan latar belakangnya dan intensitas rangsangannya yang paling kuat.

3. Nilai dan kebutuhan individu

Seseorang seniman pasti punya pola dan cita rasa yang berbeda dalam pengamatannya dibanding seorang yang bukan seniman.

4. Pengalaman dahulu

Pengalaman-pengalaman terdahulu sangat mempengaruhi bagaimana seseorang mempose dunianya.

Persepsi terbentuk dari informasi-informasi yang berada dari dalam diri kita sendiri, dari lingkungan kita. Ada tiga cara informasi masuk ke otak kita yaitu:

1. Informasi yang masuk dengan jalan dipaksakan stimulus atau rangsangan yang dipaksakan ini ialah stimulus yang tidak kita cari terpaksa kita terima

2. Adalah kita hadapkan pada berbagai stimulus dan kita memilih stimulasi yang ada dihadapan kita.

3. Adalah kita mencari stimulasi tertentu orang seringkali menggangap bahwa persepsi menyajikan satu pencerminan yang sempurna mengenai realitas atau kenyataan. Persepsi bukanlah cermin. 
Dalam sebuah organisasi, terdapat beberapa karyawan yang lebih efektif dibanding yang lainnya. Hal ini dikarenakan adanya perbedaan individu atau karakteristik yang mana membedakan satu individu dengan individu lainnya. Memilih seseorang/pegawai yang tidak benar akan menimbulkan masalah dalam hal pekerjaan, bahkan dapat merugikan kantor atau perusahaan, seperti hilangnya pelanggan, sering absen, peralatan kantor atau perusahaan rusak. Bahkan di beberapa organisasi biaya karyawan yang tidak efektif meningkat drastis, hal ini dikarenakan organisasi tidak mau memiliki mekanisme untuk mengindentifikasi, mengembangkan atau bahkan memberhentikan karyawan yang tidak efektif tersebut. Perlu memahami manusia dalam organisasi untuk memecahan permasalahan individu. Asumsi dasar untuk memahami manusia menurut Davis dan Newstrom (2014:29)

\section{Pengertian dan arti organisasi}

Para ahli memberikan definisi tentang organisasi dari berbagai sudut pandang dan bahkan ada yang memberikan definisi menurut kebutuhan.Organisasi pada umumnya diartikan sebagai bentuk kerja sama yang terdiri dari dua orang atau lebih dan bekerja berdasarkan aturan yang tertentu untuk mencapai tujuan yang telah ditetapkan sebelumnya. Berdasarkan pengertian ini dapat diambil kesimpulan bahwa organisasi terdiri unsur-unsur.

1. Dua orang atau lebih

2. Kerja sama

3. Tujuan yang ingin dicapai.

Robbins (2017,4) mendefinisikan organisasi adalah sebagai berikut: “an organization is a consciously coordinated social entitly wich a relatively identifiable boundry that function on a relatively continuous basis to achieve a common goal or set of goals". Definisi ini mengisyaratkanbahwa seseorang individu tidak akan mencapai suatu tujuan yang diinginkan secara individu yang lain. Dalam organisasi perilaku individu mengarah pada pencapaian tujuan melalui kerja sama secara efektif dan efisien dalam berkelompoksecara terpandu, Secara implisit menurut LF.Urwick bahas organisasi sangat besar pengaruhnya kepada perilaku individu dalam mencapai tujuan yang diinginkan secara kelompok. Menurut Terry (2017) organisasi adalah aturan kerja sama antara dua orang atau lebih untuk mencapai tujuan yang telah di tetapkan dengan melakukan pembagian tugas tertentu. 


\section{Alasan Terbentuknya Organisasi}

Manusia sebagai makhluk "zoon politicon" (makhluk social) tentunya mempunyai keinginan untuk hidup selalu berhubungan dengan orang lain untuk memenuhi kebutuhan melalui organisasi, Hiks,(2017:5) menyajikan sejumlah alasan mengapa manusia perlu menciptakan organisasi yaitu:

\section{Alasan Organisasi}

Organisasi dibentuk memang untuk memenuhi kebutuhan manusia dan untuk pergaulan, hal ini terlihat pada organisasi yang memilikisasran intelektual atau ekonomi. Adakalanya kebutuhan sosial manusia lebih menonjol di tempat kerja sehingga ada istilah “pekerjaan adalah kehidupan”. Jadi dapat dikatakan bahwa manusia berorganisasi karena ia membutuhkandan menikmati kepuasaan-kepuasan sosial yang diberikan oleh organisasi.

\section{Alasan Material}

Selain untuk memenuhi kebutuhan sosial dengan beroganisasi manusia juga ingin memenuhi kebutuhan materialnya. Melalui organisasinya dapat melakukan tiga hal yang tidak mungkin dilakukan manusia secara sendiri yaitu:

1. Ia dapat meningkatkan kemampuan.

2. Ia dapat menghemat waktu yang diperlukan untuk mencapai sarana, melalui bantuan sosial sebuah organisasi.

3. Ia dapat mengambil manfaat dsri pengetahuan generasi-generasi sebelumnya, yang telah dihimpun.

\section{Fungsi budaya organisasi}

Menurut Robbins (,2017:4) budaya organisasi mempunyai beberapa fungi :

1. Budaya mempunyai suatu peran pembeda. Hal itu berarti bahwa budaya kerja menciplakan pembedaan yang jelas antara satu organisasi dengan organisasi yang lain.

2. Budaya organisasi membawa suatu identitas bagi anggota-anggotanya.

3. Budaya organisasi mempermudah timbul pertumbuhan komitmen pada suatu yang lebih luas dari kepentingan diri individual 
4. Budaya organisasi itu meningkatkan kemantapan sishem sosial.

Seperti telah disebutkan di atas, bahwa dengan berorganisasi, pencapaian tujuan dapat menjadi lebih efektif. Secara spesifik organisasi dapat memberikan beberapa manfaat bagi masyarakat dan bisnis yaitu:

1. Mengubah kehidupan masyarakat

Manfaat ini bisa kita amati dari banyaknya organisasi yang membuat kehidupan menjadi Iebih baik. Organisasi kesehatan bisa membentuk masyarakat yang sehat jasmaninya. Organisasi pendidikan membentuk masyatakat yang cerdas. Organisasi kemiliteran dan kepolisian membuat kehidupan menjadi aman dan tentram.

2. Memudahkan pencapaian tujuan.

Dengan berorganisasi pencapaian tuiuan akan lebih efektif.

3. Organisasi menawarkan karir

Organisasi meru pakan kumpulan orang-orang yang memiliki pengetahuan, keterampilan dan tujuan. Oleh sebab itu, pengembangkan karir clan pengetahuan seseorang akan dapat diupayakan dengan berorganisasi. Organisasi akan selalu menawarkan karir yang lebih bila seseorang ingin meningkatkan pengetahuan dan keterampilannya.

4. Organisasi sebagai cagar ilmu pengetahuan

Dengan berorganisasi, ilmu pengetahuan akan dapat ditingkan terus. Sejarahsejarah masa lain dapat didokumentasikan dengan baik. Penelitian dan pengembangan dapat terus dilaksanakan. Sehlngga pekerjaan yang tidak dilakukan sendiri dapatl diselesikan secara bersama (organisasi)

\section{METODE PENELITIAN}

Lokasi atau tempat penelitian ini dilaksanakan di Universitas Trunojoyo Madura. Waktu yang digunakan dalam penelitian ini sekitar satu minggu. Adapun pengaturan jadwal penelitian dimulai dari tahap persiapan sebelum pembagian kuesioner. membuat pertanyaan, mengumpulkan data yang terdiri atas informasi partisipan dan teks dari sumber-sumber tertulis, menguraikan dan menganalisis data untuk menciptakan tema, dan melakukan pemeriksaan dengan cara yang subyektif (Creswell,2008) dengan Angket yang di edarkan dibagikan pada anggota organisasi yang masih aktif dan yang sudah tidak aktif dalam Unit Kegiatan Mahasiswa (UKM). 
Penelitian ini menggunakan pendekatan kualitatif yang di aman lebih pada penekanan analisis pada proses penyimpulan deduktif dan induktif serta analisis dinamika, hubungan yang diamati dengan menggunakan ilmiah. Sedangkan menurut Nana Syaodih Sukmadinata (2007:94) penelitian kualitatif ditujukan untuk memahami fenomena social dari sudut atau perspektif partisipan. Penelitian ini termasuk dalam penelitian deskribtif, dimana penelitian ini akan menggambarkan dalam bentuk cerita tentang persepsi mahasiswa pada suatu organisasi. Penelitian deskribtif ditujuksn untuk mendeskribsikan atau menggambarkan fenomena-fenomena yang ada (Nana Syaodih Sukmadinata, 2007:73)

Teknik pengumpulan data menggunakan kuesioner yang di edarkan pada 20 mahasiswa sebagai sampel namun di bagi menjadi dua kubu yaitu 10 mahasiswa yang masih aktif dan 10 mahasiswa yang sudah tidak aktif dalam Unit Kegiatan Mahasiswa. Subjek dalam penelitian ini adalah Mahasiswa yang mengikuti UKM di Universitas Trunojoyo Madura sementara itu objek dalam penelitian ini adalah UKM yang ada di Universitas Trunojoyo Madura. Tujuan dari teknik pengisian kuesioner atau pengisian angket ini yaitu untuk mengetahui atau memperoleh data mengenai bagaimana penerapan time management pada mahasiswa yang mengikuti UKM di Universitas Trunojoyo Madura, serta bagaimana pandangan atau persepsi mahasiswa terhadap suatu organisasi. Tidak hanya itu penelitian ini juga berguna untuk mengetahui bagaimana minat seorang mahasiswa dalam berorganisasi. 


\section{HASIL DAN PEMBAHASAN}

Tabel 1. Mahasiswa yang masih aktif di organisasi

\begin{tabular}{|l|c|c|}
\hline \multicolumn{1}{|c|}{ Pertanyaan } & Ya & Tidak \\
\hline $\begin{array}{l}\text { Apakah kamu dapat menerapkan time management dalam } \\
\text { kegiatan berorganisasi? }\end{array}$ & 6 & 4 \\
\hline Apakah time management itu bermanfaat? & 5 & 5 \\
\hline Apakah time management mempengaruhi persepsi mu? & 7 & 3 \\
\hline $\begin{array}{l}\text { Apakah time management mempengaruhi aktif dan } \\
\text { tidaknya kamu dalam berorganisasi? }\end{array}$ & 6 & 4 \\
\hline $\begin{array}{l}\text { Apakah time management mempengaruhi perilaku kamu } \\
\text { dalam berorganisasi? }\end{array}$ & 7 & 3 \\
\hline $\begin{array}{l}\text { Menutut kamu apakah time management itu penting? } \\
\text { Menurut kamu penerapan time management yang tidak } \\
\text { efisien dapat membawa dampak yang kurang baik? }\end{array}$ & 5 & 5 \\
\hline
\end{tabular}

Dari kuesioner yang di sebarkan mayoritas responden menjawab bahwa time management sangat mempengaruhi persepsi dan keaktifan seorang mahasiswa dalam suatu organisasi. Berikut merupakan kuesioner yang di serbarkan.

Tabel 2. Mahasiswa yang sudah tidak aktif di organisasi

\begin{tabular}{|l|c|c|}
\hline \multicolumn{1}{|c|}{ Pertanyaan } & Ya & Tidak \\
\hline $\begin{array}{l}\text { Apakah kamu dapat menerapkan time management dalam } \\
\text { kegiatan berorganisasi? }\end{array}$ & 8 & 2 \\
\hline Apakah time management itu bermanfaat? & 5 & 5 \\
\hline Apakah time management mempengaruhi persepsi mu? & 6 & 4 \\
\hline $\begin{array}{l}\text { Apakah time management mempengaruhi aktif dan } \\
\text { tidaknya kamu dalam berorganisasi? }\end{array}$ & 2 & 8 \\
\hline $\begin{array}{l}\text { Apakah time management mempengaruhi perilaku kamu } \\
\text { dalam berorganisasi? }\end{array}$ & 4 & 6 \\
\hline $\begin{array}{l}\text { Menutut kamu apakah time management itu penting? } \\
\text { Menurut kamu penerapan time management yang tidak } \\
\text { efisien dapat membawa dampak yang kurang baik? }\end{array}$ & 9 & 1 \\
\hline
\end{tabular}


Baik mahasiswa yang masih aktif di organisasi ataupun yang sudah tidak aktif di organisasi, peerapan time management dalam kegiatan berorganisasi itu sangat penting dan mayoritas mahasiswa yang sudah tidak aktif pada suatu UKM di Universitas Trunojoyo Madura sudah dapat menerapkan time management begitupun dengan yang masih aktif dalam kegiatakan berorganisasi. Tidak hanya itu time management dapat mempengaruhi perilaku dan persepsi seorang mahasiswa baik yang sudah tidak terikat pada suatu organisasi maupun yang masih terikat pada UKM atau suatu organisasi di Universitas Trunojoyo Madura.

\section{Hal Penting yang Diperhatikan dalam Perancangan Time Management}

Untuk mengelola waktu secara efektif, masing-masing harus memiliki gambaran yang jelas mengenai prinsip-prinsip serta nilai utama kehidupannya. Seorang butuh menginvestasikan sumber daya berharga dari waktu untuk hal yang sangat penting. Scott (dalam Adebisi, 2013) memperjelas bahwa satu tantangan mendasar time management yang efektif adalah memahami perbedaan antara "urgent" dan "important", "mendesak" dan "penting". "Mendesak" sendiri tidak membuat tugas itu penting. Hal "penting" itu terkait dengan prinsip pribadi. Prioritas bisnis yang menentukan hal penting dari kerja. Dengan kejelasan misi dan tujuan pribadi, waktu dijadwalkan dengan tujuan definitif dalam hati.

Seorang juga perlu merumuskan apa yang dimaksud dengan time management baginya dan bagaimana itu berkaitan dengan pengelolaan hidupnya. Dalam melakukan hal ini, ada 3 hal penting dari kehidupan yang perlu diperhatikan dalam kaitannya dengan pengelolaan waktu dengan baik, yakni: pekerjaan, kehidupan keluarga (termasuk temanteman) dan diri sendiri (Atkinson, 2009). Seorang perlu memikirkan dengan baik hal penting yang ingin dicapai dengan nyata: tentang tujuan yang ingin dicapai di tempat kerja, tentang tujuan yang ingin dicapai dengan keluarga, dan tentang tujuan yang berkaitan murni dengan diri sendiri.

\section{Memproteksi Waktu yang Sudah Ditetapkan}

Alan (dalam Adebisi, 2013) mencatat, kunci sukses time management adalah perencanaan dan proteksi atas waktu yang sudah direncanakan, yang sering mencakup pengondisian lingkungan, khususnya pengkondisian kembali harapan dari pihak-pihak lain 
yang terlibat. Time management adalah tentang membuat perubahan terkait dengan penggunaan waktu. Untuk memastikan keefektifan time management, seorang harus menerapkan time management system yang akan membantu untuk melihat bahwa perubahan perlu dilakukan, dalam arti bahwa tahap pertama dalam time management adalah menganalisis bagaimana ia menentukan perubahan apa yang ingin dilakukan (Susan, 2012).

Time management yang efektif tidak datang begitu saja secara alami, melainkan untuk terhindar dari bekerja mati-matian pada saat yang sudah mepet, sebaliknya dapat kesempatan besar sukses dalam bisnis, penerapan time management merupakan hal sangat penting untuk dilakukan. Pengaturan waktu yang sudah dibuat, harus diperhatikan dengan baik. Jika hal itu berkenaan dengan pengerjaan suatu proyek, setelah time management dirancang dengan baik dan ditetapkan, harus disosialisasikan dengan baik kepada pihakpihak yang terlibat. Semua pihak yang terlibat, termasuk pimpinan proyek perlu konsisten mengikuti pengaturan waktu yang telah dibuat.

Terkait dengan pengembangan time management, baik pada level organisasi maupun level pribadi, hal yang sering menjadi masalah adalah ketidakkonsistenan mengikuti rancangan penggunaan waktu yang telah dibuat. Ada kecenderungan gampang melanggar ketetapan yang telah dibuat. Tantangan yang sering muncul adalah adanya halhal yang tiba-tiba muncul dan dirasa sebagai hal penting untuk segera ditangani. Ketika hal-hal tersebut muncul dengan jumlah yang terus bertambah, sementara pengendalian diri yang baik terhadapnya tidak dimiliki, maka dengan mudah perhatian, waktu, dan tenaga tersita banyak untuk itu. Dampak semuanya itu adalah kegagalan mewujudkan misi, menelantarkan tujuan penting yang ingin diraih. Untuk menghindari hal itu, perlu kembali pada perencanaan waktu yang sudah dibuat dengan baik, yang sudah ditetapkan dengan memerhatikan di dalamnya perwujudan misi pribadi, tujuan yang ingin diraih, pemenuhan harapan terkait dengan keluarga, dan pencapaian hasil yang diinginkan oleh organisasi tempat bekerja.

\section{Manfaat Time Management}

Time management yang baik sangat penting dalam menghadapi tekanan dari kehidupan modern tanpa harus mengalami banyak stres. Waktu yang bagus di pekerjaan 
berarti melakukan pekerjaan berkualitas tinggi, bukan terutama tinggi dalam hal kuantiti. Claessens, et al (2007) menemukan bahwa menggunakan teknik time management akan berhubungan langsung dengan kinerja dan kepuasan, serta dapat mengurangi kegalauan dan kecemasan.

Time management menghadirkan skills, tools, dan kemampuan melakukan hal yang benar pada waktu yang benar, dengan usaha minimal dan sumber daya minimal, efektif dan efisien, yang melaluinya seorang bisa mencapai tujuan dan nilai-nilai personal yang diprioritaskan. Time management membuat orang menjadi penting dan terhormat, mampu mengorganisasi hal-hal di sekitar, serta membuat seseorang mampu mengoptimalkan kinerja. Kebutuhan terhadap time management sudah makin diakui, dianggap penting bukan hanya sebagai sebuah unsur motivasi di belakang kinerja karyawan dan produktivitas, melainkan juga sebagai dasar dari semua kinerja organisasi. Dalam dunia bisnis, waktu adalah salah satu aset penting bagi apa saja dalam organisasi. Penting untuk melatih karyawan dalam hal manajemen waktu yang sistematis, sehingga mereka dapat mencapai hasil produktivitas dalam periode waktu yang sudah ditentukan.

Kinerja organisasi maksudnya adalah tempat organisasi itu dalam hubungannya dengan pesaingnya terkait dengan market share, profit dan capital base. Organisasi sedemikian dibangun melalui kontribusi positif dari karyawannya bagi keberhasilan organisasi (Adebisi, 2013). Pimpinan yang mempunyai visi, determinasi dan fokus jelas akan membangun organisasi yang memiliki kinerja

\section{KESIMPULAN DAN SARAN}

Manajemen waktu tentunya berpengaruh akan persepsi dan perilaku mahasisa dalam suatu organisasi, apabila seorang mahasiswa tidak dapat menyusun jadwal kegiatan atau perencanaan kegiatan yang akan di lakukan maka tentunya hal itu aka mengganggu aktivitas mahasiswa tersebut, tidak hanya itu kurangnya manajemen waktu juga akan membentuk suatu persepsi mahasiswa yang di mana akan membentuk pola pikir atau sudut pandang mahasiswa tersebut akan mana hal yang harus di lakukan terlebih dahulu atau mana yang harus di prioritaskan. Sehingga terbentuklah perilaku mahasiswa tersebut, mahasiswa yang tidak dapat manajemen waktu dengan baik akan membentuk perilaku yang kurang baik dan tentunya terjadi bentrok antara satu tugas dengan tugas lainnya. Sehingga harus ada yang di korbankan atau di tinggalkan, karena kita tidak dapat 
mengerjakan dua atau tiga kerjaan secara bersamaan. Maka sangat di perlukan manajeman waktu yang baik pada seorang mahasiswa. Apabila dalam suatu organisasi seorang mahasiswa tidak dapat membagi waktunya atau cenderung lebih aktiv pada kegiatan organisasi yang di ikuti maka aktivitas kuliah seperti membuat tugas dan belajar harus di korbankan, hal yang kadang kita sepelehkan seperti menyusun rencana kegiatan atau jadwal harian ini ternyata sangat berpengaruh dan berperan penting. Kita harus mengimbangi antara kegiatan di organisasi dan kegiatan atau aktivitas perkuliahan sehingga tidak terjadi hal-hal yang tidak kita inginkan. Dengan demikian, aktivitas kuliah kita dapat berjalan dengan baik dan kegiatan dalam organisasipun dapat terlaksanakan dengan baik. Itulah alasan mengapa manajemen waktu sangat berpengaruh pada persepsi dan perilaku seorang mahasiswa.

\section{Saran}

Manajemen waktu yang baik akan menciptakan persepsi seorang mahasiswa dan mempengaruhi bagaimana perilaku seorang mahasiswa dalam organisasi, manajemen waktu yang baik tentunya akan membawa dampak yang baik untuk kita sendiri. Manajemen waktu yang baik membentuk persepsi atau sudut pandang dan perilaku yang baik, tidak hanya itu manajemen waktu yang baik akan sangat membantu kita untuk memisahkan hal mana saja yang harus di prioritaskan dan mana yang harus di dahulukan. Sehingga satu kegiatan dan kegiatan lainnya tidak bertabrakan. Seorang mahasiswa harus bisa menempatkan dirinya dengan baik, entah dalam kegiatan berorganisasi maupun saat proses belajar mengajar atau aktivitas perkuliahan. Saran saya, akan lebih baik apabila kita sebagai mahasiswa baik dan aktif dalam organasiasi maupun yang tidak? Kita harus bisa menerapkan time management. Tidak hanya pada mahasiswa yang mengikuti atau terlibat dalam Unit Kegiatan Mahasiswa (UKM) time management sangat di perlukan bagi seorang mahasiswa.

\section{DAFTAR PUSTAKA}

Akhmad subkhi, Mohammad Jauhar. 2013. Pengantar dan Teori perilaku organisasi. Jakarta: Prestasi Pustaka

Antonius Atosokhi Gea.2014. Time Management: Menggunakan waktu secara efektif dan efisien. Vol.5 No.2 Oktober 2014: 777-785

Hendi suhendi,Sahya Anggara.2010. Perilaku Organisasi. Bandung : CV Pustaka Setia Herry.2013.Pengantar Manajemen. Jakarta : Gava Media 
Robbins, Stepen dan P Timothy A. Judge. 2014. Perilaku organisasi (OrganizationBehavior). Jakarta : Salemba Empat

Rois Arifin,Amirullab,Khalikussabir. 2017. Budaya dan perilaku organisasi. Malang : Empat Dua

Rohmaul Listyana, Yudi Hartono.2015. Persepsi dan sikap masyarakat terhadap penanggalan jawa dalam penentusn waktu pernikahan.Vol.5 No 1 Januari 2015

Toha Miftah 2014. Organisasi Konsep Dasar Dan Aplikasinya. Jakarta: PT Rajagrafindo Persada 